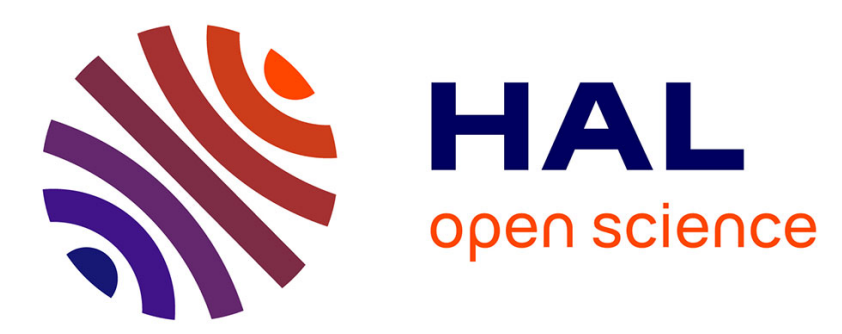

\title{
Why do women still earn less than men? Decomposing the Dutch gender pay gap, 1996-2006
}

\author{
Eva Fransen, Janneke Plantenga, Jan Dirk Vlasblom
}

\section{To cite this version:}

Eva Fransen, Janneke Plantenga, Jan Dirk Vlasblom. Why do women still earn less than men? Decomposing the Dutch gender pay gap, 1996-2006. Applied Economics, 2011, pp.1. 10.1080/00036846.2011.589818 . hal-00719069

\section{HAL Id: hal-00719069 \\ https://hal.science/hal-00719069}

Submitted on 19 Jul 2012

HAL is a multi-disciplinary open access archive for the deposit and dissemination of scientific research documents, whether they are published or not. The documents may come from teaching and research institutions in France or abroad, or from public or private research centers.
L'archive ouverte pluridisciplinaire HAL, est destinée au dépôt et à la diffusion de documents scientifiques de niveau recherche, publiés ou non, émanant des établissements d'enseignement et de recherche français ou étrangers, des laboratoires publics ou privés. 




\section{Why do women still earn less than men? Decomposing the Dutch gender pay gap, 1996-2006}

\begin{tabular}{|r|l|}
\hline Journal: & Applied Economics \\
\hline Manuscript ID: & APE-2010-0179.R1 \\
\hline Journal Selection: & Applied Economics \\
\hline Date Submitted by the & 02-Nov-2010 \\
\hline Complete List of Authors: & $\begin{array}{l}\text { Fransen, Eva; Utrecht University, Utrecht University School of } \\
\text { Economics } \\
\text { Plantenga, Janneke; Utrecht University, Utrecht University School of } \\
\text { Economics } \\
\text { Vlasblom, Jan Dirk; Utrecht University, Utrecht University School of } \\
\text { Economics }\end{array}$ \\
\hline JEL Code: & $\begin{array}{l}\text { J31 - Wage Level, Structure; Differentials by Skill, Occupation, etc. } \\
<\text { J3 - Wages, Compensation, and Labor Costs < J - Labor and } \\
\text { Demographic Economics, J71 - Discrimination < J7 - Discrimination } \\
<\text { J - Labor and Demographic Economics }\end{array}$ \\
\hline Keywords: & \begin{tabular}{l} 
Gender pay gap, wage structure, human capital, discrimination \\
\hline
\end{tabular} \\
\hline \multicolumn{2}{|c}{} \\
\hline
\end{tabular}




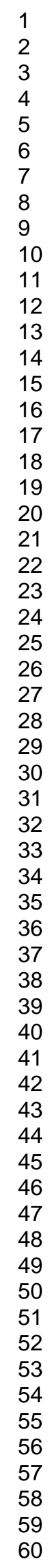

\section{SCHOLARONE ${ }^{m}$ \\ Manuscripts}

7

25

26

27

29

30

31

33

34

35

36

37

38

41

42

43

45

46

47

48

49

51

52

53

54

55

57

58

59

60 


\title{
Why do women still earn less than men? Decomposing the Dutch gender pay gap, 1996-2006
}

\author{
Eva Fransen, Janneke Plantenga and Jan Dirk Vlasblom* \\ Utrecht University School of Economics \\ Janskerkhof 12, 3512 BL Utrecht, Netherlands \\ *Corresponding author: E-mail: j.d.vlasblom@uu.nl
}

Despite major improvements in women's labour market attachment, women still earn considerably less than men. International research shows that the persistence of the gender pay gap may be due to the fact that although the gap in characteristics between men and women is diminishing, changes in the wage structure counteract this change. This article will study whether this 'swimming upstream' phenomenon is also playing a role in the rather slow convergence between male and female wages in The Netherlands. Our results indicate that this is not the case; most of the changes in the Dutch wage structure have been rather favourable to women. The lacking convergence in wages has to be explained from the fact that despite the favourable changes, the Dutch wage structure still contains a considerable implicit gender bias. 


\section{Introduction}

Despite major improvements in women's labour market attachment, the Dutch gender pay gap is still substantial. According to various sources, women earn approximately $20 \%$ less then men and this difference seems to decrease only slowly. The average gender pay gap in Europe is $17 \%$ and the Netherlands are outperformed by countries as Belgium, Italy, Denmark, France and Finland (See e.g. Mandel and Semyonov, 2005; Plantenga and Remery, 2006).

The causes of the gender pay gap have been investigated rather thoroughly during the 1970's and 80's. During that period, the pay differential was often explained within the context of human capital theory and discrimination. According to human capital theory, women are less successful on the labour market than men because of differences in individual characteristics like education and experience. In order to reduce gender earnings inequality, government policy at that time was strongly targeted towards increasing women's educational levels and labour force participation rates. At the same time, discrimination was tackled by "equal pay for equal work"-legislation that was implemented in the Netherlands in 1975. The strategy has been rather successful in the sense that women have realized great improvements in their levels of educational attainment. In addition, women's employment rates have increased with each younger cohort for every age category (OECD, 2002). As this implies that women have been increasingly well-positioned for successful labour market participation, the persistent of the gender pay gap seems rather puzzling. Why hasn't the gap been closed?

Recent international research on the gender pay gap suggests that pay differences may not only be the result of differences in human capital variables, but are also influenced by a country's wage structure. That is "the array of prices set for various labour market skills (measured and unmeasured) and rents received for employment in particular sectors of the economy" (Blau and Kahn, 1996b). As men and women differ with respect to experience or work in different sectors, any changes in returns to experience or any difference in the sectoral pay level will have an impact on the gender pay gap (Blau and Kahn, 2003). These changes in the wage structure ('prices') could offset the progress that women have made in terms of human capital equalization ('characteristics'). 
Given this outcome from international research, the question can be raised whether this 'swimming upstream' (Blau and Kahn, 1997) also plays a role in the persistence of the Dutch gender pay gap. By making use of micro data, covering 1996 and 2006, the change in the gender pay gap is decomposed in several factors, like changes in the human capital and changes in the wage structure. The next section first provides a short overview of the theoretical considerations and previous literature, Section 3 describes the decomposition approach and Section 4 presents the data and the estimation results. Section 5 shows the decomposition results and Section 6 concludes.

\section{Theoretical Considerations and Previous Research}

The traditional and still widely used way of analyzing the gender pay gap is the method used by Oaxaca (1973) and Blinder (1973). They argue that there exist two separate labour markets for men and women and that male and female human capital is rewarded to their own demand and supply levels. The gender pay difference is thus influenced by differences in human capital of the two groups as well as by the different rewards for human capital in the two separate markets. In recent years, however, there are more and more authors that argue that there is in fact only one labour market in which prices are determined to total demand and supply (Blau and Kahn, 1996a; 1996b; 2003; Olsen and Walby, 2004; Datta Gupta et al., 2006; Heinze, 2009). In the view of these authors men and women earn the same in comparable jobs. The fact that they do not earn the same indicates that in general they do not have comparable jobs. Therefore, in their arguing, not only human capital factors are relevant, but also more institutional factors such as the level of occupational segregation and the prices set for certain labour market skills and/or rents received for working in particular sectors, in short, the wage structure (Blau and Kahn, 1996b).

The wage structure is affected by the structure of labour supply and demand, technological change and the country's wage-setting institutions. Strongly innovative firms, for example, may pay higher wages for skilled workers. If a higher incidence of workers in those innovative firms or sector(s) is male, this is likely to increase the gender pay gap, all else equal. Institutional factors also play a role in the sense that 
centralized wage-setting institutions are likely to reduce inter-firm and inter-industry wage variation and may thereby lower the gender pay gap. Minimum wage floors determine the wages of those at the bottom of the wage distribution. As in practically all countries the female wage distribution lies below the male wage distribution, raising minimum pay levels will benefit women more than men (See e.g. Plantenga and Remery, 2006). In contrast, decentralization and individualization of the pay system could result in an increase of the gender pay gap and could thus offset the progress that women have made in terms of human capital equalization. Blau and Kahn (1997) for example find that rising overall wage inequality in the United States slowed women's progress during the 1980's, reclaiming about one-third to two-fifths of women's potential wage gains. Datta Gupta et al. (2006) also attributed the stagnation of the wage gap in the Nordic countries to unfavourable wage structure effects, which in Denmark more than wiped out any gains that Danish women had made in their human capital over the period.

\section{Dutch research}

So far, the Dutch research in the area of gender pay differentials has been rather limited. Schippers (1987) performed an extensive study on gender pay differentials in the 1980's and found that the gender pay gap in the Netherlands was mainly the result of men and women being spread unequally over occupation-levels as opposed to being paid unequally within occupations. He also concluded that human capital differentials were insufficient to explain the total gender pay gap and stated that a large part of the unexplained differential could be attributed to discrimination of some sort. Tijdens et al. (2002) also decomposed the gender pay gap into differences in characteristics and discrimination, but in addition to Schippers also included workrelated characteristics, such as job tenure, firm size and collectively agreed wages. Using data from the Wage Indicator Survey, they found that $71.5 \%$ of the pay gap was explained by differences in characteristics, leaving an unexplained part of $28.5 \%$ (Tijdens et al., 2002).

Other quantitative studies that have been performed in the past ten years focused on a single cause or specific gap rather than decomposing the gender pay gap as a whole. For example, De Ruijter et al. (2003) looked at the relation between gender-specific occupations and pay and found that there is a wage penalty 4 
associated with working in a female-dominated occupation and that this wage penalty is rather large for both men and women. Compared to the United Kingdom or the United States, however, the wage penalty appears rather small due to the more compressed wage structure in the Netherlands. In addition, the availability of relative well paid part-time jobs in the Netherlands translates into a relatively small occupational gender pay gap. Albrecht et al. (2004) studied the gender pay gap for fulltime workers using data from the 1992 wave of the OSA-panel. They concluded that most of the gender pay gap across the distribution is explained by differences in returns to characteristics, as opposed to differences in characteristics themselves. Also Van der Meer (2008), using OSA data covering the period 1986-1998 shows that the wage gap is mainly due to price differences, and not to differences in characteristics or gender related productivity differences. Russo and Hassink (2008) conclude that the wage gap between men and women is an (indirect) effect of working part-time. The larger part of wage increases is due to promotion. However, part-time workers have a smaller probability of promotion than full-time workers. As women tend to be more on part-time jobs than men, this will cause a gender wage gap amongst (especially) more mature workers.

Summarizing the results from the previous Dutch literature, there seems to be a certain consensus over the fact that there is more to the gender pay gap than just a difference in human capital. However, most studies focus on a single feature of the gender pay gap and therefore do not provide a complete picture as to why women still earn less than men.

\section{Research Design}

In order to analyse the Dutch gender pay gap we follow the research design of Blau and Kahn (1997; 2004; 2006). Their design is based on the so-called Juhn-MurphyPierce (JMP) decomposition (Juhn et al., 1991; 1993). In this framework a nondiscriminatory wage equation is estimated, which is then used to compare the wages of the discriminated group to those of the non-discriminated group. Following Juhn et al.. we assume the male wage equation is reflecting the non-discriminatory wage structure:

$$
\ln \mathrm{Y}_{m t}=\mathrm{X}_{m t} \beta_{t}+\sigma_{t} \theta_{m t}
$$


where $\mathrm{Y}$ is the hourly wage rate, $\beta$ the vector of coefficients, $\mathrm{X}$ a vector of individual- and work-related characteristics. In this equation $\sigma$ is the standard deviation of the unexplained part (i.e. the dispersion of the residual wage distribution) and $\theta$ gives the standardized residual, and as such, is an indication for the position of an individual in the residual wage distribution. The subscript $t$ refers to the year, while the subscript $m$ refers to the male values. Based on this single wage regression, the wage gap in year $t$ can be written as:

$$
\operatorname{Gap}_{t}=\ln \mathrm{Y}_{m t}-\ln \mathrm{Y}_{f t}=\left(\mathrm{X}_{m t} \beta_{t}+\sigma_{t} \theta_{m t}\right)-\left(\mathrm{X}_{t t} \beta_{t}+\sigma_{t} \theta_{f t}\right)=\Delta \mathrm{X}_{t} \beta_{t}+\Delta \theta_{t} \sigma_{t}
$$

where $\Delta$ signifies the average male-female differential in a given year. In the right hand part of Equation 2 the first term is referred to as the 'quantity effect', and the second term as the 'residual gap'. The change in the gender wage gap now becomes:

$$
\text { Gapchange }=\left[\Delta \mathrm{X}_{1} \beta_{1}-\Delta \mathrm{X}_{0} \beta_{0}\right]+\left[\sigma_{1} \Delta \theta_{1}-\sigma_{0} \Delta \theta_{0}\right]
$$

which is essentially the sum of the change in the quantity effect and the change in the residual gap. Taking year 1 as the reference year, the above equation can be slightly rewritten in to four parts:

$$
\text { Gapchange }=\left(\Delta \mathbf{X}_{1}-\Delta \mathbf{X}_{0}\right) \beta_{1}+\Delta \mathbf{X}_{0}\left(\beta_{1}-\beta_{0}\right)+\left(\Delta \theta_{1}-\Delta \theta_{0}\right) \sigma_{1}+\Delta \theta_{0}\left(\sigma_{1}-\sigma_{0}\right)
$$

These four parts all show a different effect that contributes to the change in the gender wage gap

$$
\begin{array}{ll}
\text { observed X's effect: } & \left(\Delta \mathrm{X}_{1}-\Delta \mathrm{X}_{0}\right) \beta_{1} \\
\text { observed prices effect: } & \Delta \mathrm{X}_{0}\left(\beta_{1}-\beta_{0}\right) \\
\text { gap effect: } & \left(\Delta \theta_{1}-\Delta \theta_{0}\right) \sigma_{1} \\
\text { unobserved prices effect: } & \Delta \theta_{0}\left(\sigma_{1}-\sigma_{0}\right)
\end{array}
$$

Equation 5 reflects the changes in the gender differences in pay that can be related to different characteristics of men and women: i.e. given the prices, a change in a difference in characteristics has an effect on the wage differential. The observed prices effect in Equation 6 is the impact of a change in prices over time: given differences in characteristics, a change in prices has an effect on the wage differential. The gap effect in Equation 7 reflects the impact of a change in the relative position that women have in the male residual wage distribution, i.e. the part of the change in the wage differential that can be attributed to the fact that women's positions within the residual distribution change. Finally, the unobserved prices effects in Equation 8 is the part of the change in the wage differential that can be 
attributed to the fact that the residual inequality (the dispersion) of the wage distribution changes. The gender related differences are thus given by Equations 5 and 7 above, as these are directly related to gender differences in observed and unobserved characteristics. The (changes in the) wage structure are reflected in Equations 6 and 8 above.

In contrast to the more familiar Oaxaca-Blinder decomposition types, in this decomposition there is only a price difference between years, and not between groups within a given year. Aspects of discrimination are therefore not reflected in the observed characteristics effect or the observed prices effect. Rather, direct discrimination is reflected by the position in the residual distribution (the gap effect as reflected in Equation 7 above). Discrimination will thus lead to a position in the lower tail of the residual distribution. Given the price of deviating from the 'average male', this position in the lower tail of the residual distribution will lead to a lower wage. As stated above, the actual impact depends on nature of the wage distribution: in case of a compressed residual distribution the impact will be limited.

Notice that the JMP-decomposition is not without its problems. There is the usual discussion with respect to the choice of the reference group (male/female/total population). Taking another reference group will lead to a different outcome of the decomposition, as the outcome depends on the estimated prices. Also, the decomposition of the residual can only be interpreted on the basis of some fairly strong assumptions (See e.g. Yun, 2009). However, the JMP-decomposition does make it possible to relate the wage gap to both institutional factors (as influencing the dispersion of the residual) and aspects of discrimination (as reflected by the relative position of women in the distribution).

\section{Data and Estimation Results}

Data for our decomposition analysis are obtained from the labour supply panel of the Organization of Strategic Labour Market Research (OSA) of 1996 and 2006. This is a labour market survey held among approximately 5000 individuals that are currently in the potential labour force. The survey provides both personal and work-related information. With respect to education, it has detailed data on a person's educational attainment. Regarding lifetime working patterns, OSA provides 
information on age, years of experience and job tenure. It also contains work related information like type of work, firm size, sector, supervision responsibilities and level of the occupation, as well as net monthly income and working hours. These last two allow for the computation of hourly wages. For this study, using net income might be a problem, as the Dutch progressive tax system causes net wages to be more equalized than gross wages. ${ }^{1}$ It is possible however, to estimate a gross income based on reported net income, and using a couple of job and household characteristics. This type of net-gross transformations has been used in previous research using the OSAdata (See e.g. Grift, 1998; Vlasblom, 1998). ${ }^{2}$ Only observations of those who are currently employed with an employer are used; those attending daytime education have been excluded. We also excluded cases with missing or incorrect information. This leaves us with 2544 observations in 1996 and 2762 in 2006. The logarithm of the derived gross hourly wage rate is used as the dependent variable.

On the basis of the OSA data, Figure 1 presents the wage distributions in 1996 and $2006 .^{3}$ It appears that in both years the male distribution is more dispersed and shifted to the right compared to the female wage distribution. This is consistent with all studies that show that women are overrepresented in the lower tails of the wage distribution. Comparing the 1996 and 2006 distributions, we can see that for both men and for women, the distribution has shifted upward. This suggests that although women started to earn more, their relative position compared to men changed only slightly. Our data show that the uncorrected gender wage gap declined by 6.7 percentage points to a gap of around $18 \%$ in 2006 .

\footnotetext{
${ }^{1}$ See also Van der Meer (2008) who reports a 5 percentage points difference in the before and after tax gender wage gap.

${ }^{2}$ For both years, the transformation was done using the basic tax-tariffs, the general deductions, and the payments to pensions and social security. Not taken into account were housing related costs and deductions, the tax-effects of employer provided cars and other non-monetary forms of payment. This implies that our estimates will be an overestimation of the real gross income.

${ }^{3}$ For this graph we used the consumer price index (CPI) as published by Statistics Netherlands (CBS) to make the number comparable. Wages are computed at the 2006-price level
} 


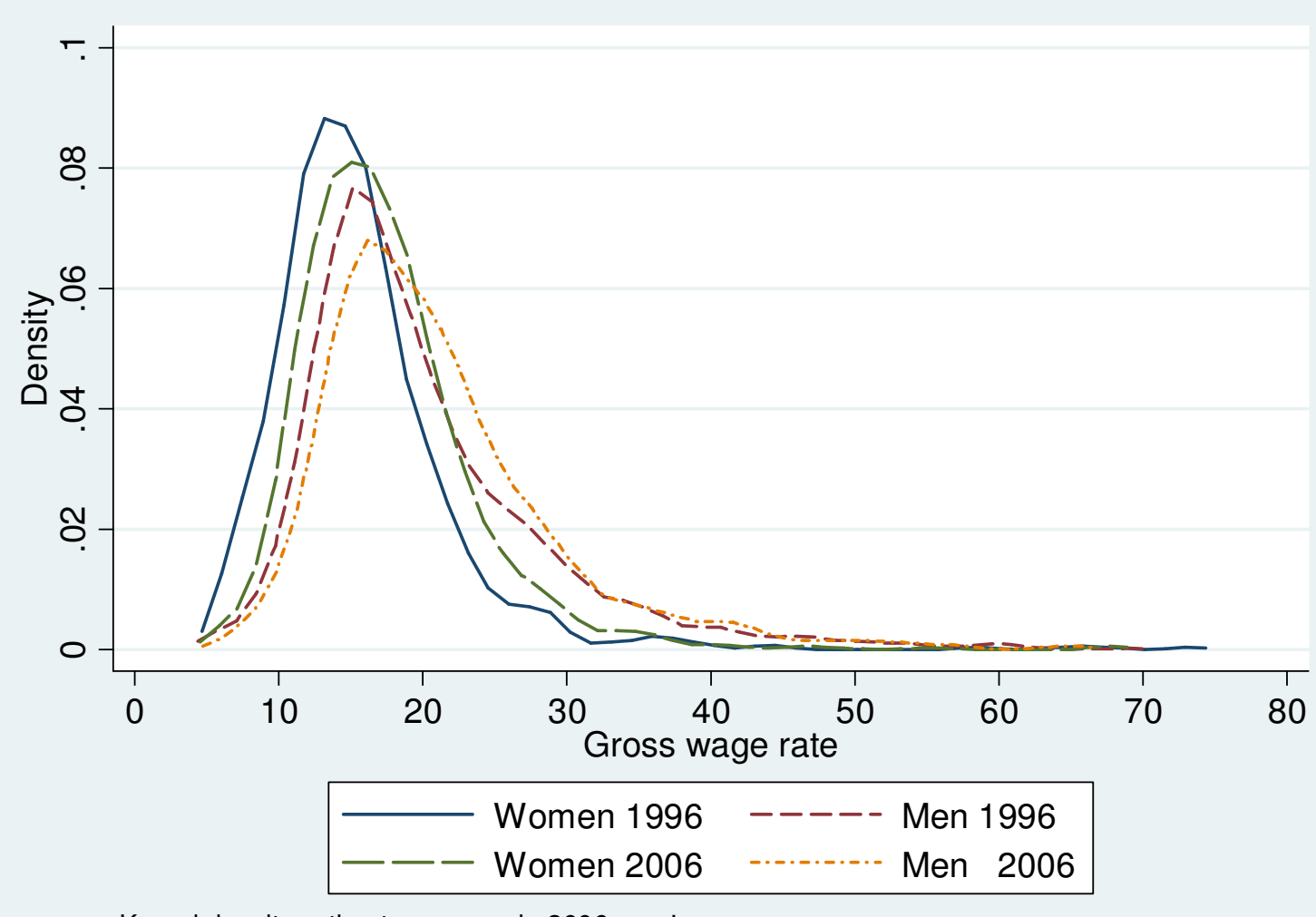

Kernel density estimates, wages in 2006 euro's

Figure 1. Gross wage distribution of men and women, 1996 and 2006

Source: OSA Labour supply panel 1996/2006

With regard to the characteristics of male and female employees, Table 1 shows the life-course related factors in both years: age, experience, and indicators of the household composition. It can be seen that over this decade there has been a greying of the Dutch labour force: the average age of the working individuals increased. Directly connected to this trend, there is a strong increase in the work experience of workers. The increase for women has been larger, as for this group two trends were present: the first was the general greying of the population, and the second one the diminishing exit-rates at marriage and child-birth.

Table 1. Life course related variables

\begin{tabular}{lrrrr}
\hline & \multicolumn{2}{c}{1996} & \multicolumn{2}{c}{2006} \\
& \multicolumn{1}{c}{ Men } & Women & Men & Women \\
\hline Age & 38.82 & 37.02 & 43.43 & 41.18 \\
Experience & 19.63 & 13.92 & 23.14 & 18.04 \\
$\quad$ exp $<=5$ years & 0.11 & 0.17 & 0.05 & 0.07 \\
$\quad$ exp $>12$ years & 0.70 & 0.53 & 0.83 & 0.73 \\
Living with partner & 0.78 & 0.77 & 0.85 & 0.78
\end{tabular}


Table 2. Educational related variables, working population

\begin{tabular}{lcccc}
\hline & \multicolumn{2}{c}{1996} & \multicolumn{2}{c}{2006} \\
& Men & Women & Men & Women \\
\hline Educational level & & & & \\
$\quad$ Primary & 0.05 & 0.04 & 0.02 & 0.02 \\
$\quad$ Lower secondary & 0.34 & 0.30 & 0.21 & 0.21 \\
$\quad$ Upper secondary & 0.38 & 0.44 & 0.39 & 0.41 \\
$\quad$ Lower tertiary & 0.17 & 0.20 & 0.26 & 0.26 \\
$\quad$ Upper tertiary & 0.06 & 0.03 & 0.11 & 0.10 \\
Field of education & & & & \\
$\quad$ General & 0.35 & 0.39 & 0.26 & 0.32 \\
$\quad$ Agriculture/Technics & 0.47 & 0.04 & 0.40 & 0.06 \\
$\quad$ Economics/Law & 0.09 & 0.14 & 0.19 & 0.17 \\
$\quad$ Medical & 0.02 & 0.29 & 0.05 & 0.21 \\
$\quad$ Education & 0.07 & 0.14 & 0.11 & 0.24 \\
\hline N $\quad 1541$ & 1003 & 1407 & 1355 \\
\hline Source: OSA Labour supply panel 1996/2006 & &
\end{tabular}

Table 2 also shows that there has been a small shift in the choice of educational field of the workforce. These changes are relatively small and seem to be driven mainly by the overall changes in the economy. In addition, some gender differences can be ascertained. These may be related to the initial choice of individuals for a level and field of education. In addition, there is -for women- again the participation effect: in case exit-rates changed for the various types of education, this also changes the 
composition of the labour force. Overall, the distribution seems to have become more equal, which could have contributed to a more equal pay between men and women. Finally, in Table 3 we present information with respect to the job-characteristics. This refers to both the job-level and the sector of industry. Despite the changes over the last decade with respect to education, participation and experience, not much has changed with respect to the type of job women are in. Variable pay became common practice, but as the question also includes a non performance related $13^{\text {th }}$-month, this change is not too informative. With respect to firm size, it can be seen that for both men and women it became slightly more common to work in larger firms. Nevertheless, women more often work in a small firm and this difference hasn't changed much. With respect to the job level, we have two indicators: the first relates to the skill level needed for the job and is directly related to the so-called SBC (Standaard Beroepen Classificatie, Standard Classification of Occupations). It appears that in 1996 women were, on average, on lower levels than men. By 2006, women have reached the levels of men in 1996. However, over the last decade, also the number of men in higher occupations increased. As a result, the gender gap in job level increased as the difference between the percentage of men and women working in higher job levels was around 7 percentage points in 1996, compared to 10 points in 2006. The other measure is whether or not any managerial or supervising tasks are involved in the job, as reflected by the number of employees that are supervised. The relative difference of men and women seems to have remained rather stable: less than two-third of the men had no supervisory tasks, compared to three-quarter of women. Finally it appears that the distribution over the sectors changed for both men and women. This mainly reflects the changes in the economy towards a more serviceoriented economy over the last decade. The overall difference between men and women hardly changed.

Table 3. Job-related factors, working population

\begin{tabular}{lcccc}
\hline & \multicolumn{2}{c}{1996} & \multicolumn{2}{c}{2006} \\
& Men & Women & Men & Women \\
\hline Elements of variable pay & 0.39 & 0.21 & 0.63 & 0.64 \\
Firm size & & & & \\
$\quad$ 1-25 employees & 0.24 & 0.33 & 0.23 & 0.30 \\
$\quad$ 25-50 employees & 0.14 & 0.11 & 0.13 & 0.12 \\
50-500 employees & 0.41 & 0.35 & 0.40 & 0.34 \\
$\quad$ more than 500 employees & 0.21 & 0.20 & 0.24 & 0.25
\end{tabular}




\begin{tabular}{lrrrr} 
Supervising responsibilities in job & & & & \\
No supervisory job & 0.63 & 0.84 & 0.58 & 0.78 \\
supervising 1-4 persons & 0.16 & 0.09 & 0.19 & 0.13 \\
supervising 5-9 persons & 0.08 & 0.03 & 0.10 & 0.04 \\
supervising 10-19 persons & 0.06 & 0.02 & 0.06 & 0.02 \\
supervising 20-49 persons & 0.04 & 0.02 & 0.04 & 0.02 \\
$\quad$ supervising more than 50 persons & 0.02 & 0.00 & 0.03 & 0.01 \\
Job level & & & & \\
elementary & 0.05 & 0.10 & 0.03 & 0.05 \\
lower & 0.29 & 0.32 & 0.20 & 0.30 \\
intermediate & 0.38 & 0.36 & 0.37 & 0.35 \\
higher & 0.21 & 0.18 & 0.32 & 0.25 \\
scientific & 0.08 & 0.04 & 0.08 & 0.05 \\
Sector of industry & & & & \\
agriculture & 0.02 & 0.00 & 0.01 & 0.01 \\
industry & 0.21 & 0.08 & 0.16 & 0.05 \\
construction & 0.10 & 0.01 & 0.06 & 0.01 \\
catering & 0.16 & 0.16 & 0.15 & 0.12 \\
transport and communication & 0.09 & 0.04 & 0.09 & 0.04 \\
commercial services & 0.13 & 0.14 & 0.21 & 0.16 \\
other services & 0.04 & 0.05 & 0.04 & 0.05 \\
government & 0.13 & 0.08 & 0.12 & 0.08 \\
education & 0.07 & 0.11 & 0.08 & 0.12 \\
healthcare & 0.05 & 0.33 & 0.08 & 0.37 \\
\hline $\mathrm{N}$ & 1541 & 1003 & 1407 & 1355 \\
\hline So & & & &
\end{tabular}

Source: OSA Labour supply panel 1996/2006

The tables above show the changes in the characteristics of the workforce, and the changes in the gender gap with respect to these characteristics. The wage gap between men and women, however, also depends on the prices for the various characteristics. Following Juhn et al. we assume that the male wage regression reflects the non-discriminatory prices (Juhn et al., 1991), therefore we estimate a wage regression on male wages only. Table 4 shows the results of the regressions for 1996 and $2006 .{ }^{4}$ The estimated parameters of the explanatory factors are consistent

\footnotetext{
${ }^{4}$ In the estimation of wage equations, often a procedure to correct for sample selection bias is used. (Heckman, 1974; 1979). As we only need a male wage regression for the JMP-decomposition this bias is not a problem here, and there is no need to use a Heckman approach. This in turn allows us to incorporate a number of explanatory factors that are only available for the working subsample, such as job and sector characteristics into our wage regression. Ideally, we would have liked to also include an indicator of part-time work as part-time work tends to affect wages (Russo and Hassink, 2008). However, as we needed working hours to compute wages, working hours can not be included as an explanatory variable in the wage regressions, as the estimated effect will be biased due to the so-called division bias (See Borjas, 1980).
} 
with what could be expected from the theory: the human capital-variables (education, age and experience) are very important in determining a person's wage. The effect of age is curved, indicating that the increase in wage tails off; there is a larger increase during younger years and a smaller increase in later years. The wage profile reaches its maximum around the age of 55 in 1996 and shifted upwards to 58 in 2006. As predicted by human capital theory, experience adds to wages. However, the value of experience diminished over the last decade. In 1996, having an experience of more than 15 years yielded a $31 \%$ advantage, compared to $17 \%$ in 2006 .

Table 4. Regression results for the wage equation for men, 1996 and 2006

\begin{tabular}{|c|c|c|c|c|c|c|}
\hline 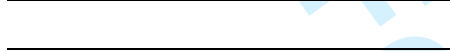 & \multicolumn{3}{|c|}{1996} & \multicolumn{3}{|c|}{2006} \\
\hline & Beta & SE & t-value & Beta & SE. & t-value \\
\hline Age (years) & $0.020 * * *$ & -0.007 & 2.92 & $0.034 * * *$ & -0.007 & 5.03 \\
\hline $\mathrm{Age}^{2} / 100$ & $-0.014^{*}$ & -0.008 & 1.78 & $-0.029 * * *$ & -0.007 & 3.85 \\
\hline \multicolumn{7}{|l|}{ Work experience } \\
\hline 0 till 3 years & ref. & & & ref. & & \\
\hline 3 up to 5 years & $0.172 * * *$ & -0.037 & 4.70 & $0.107 *$ & -0.056 & 1.89 \\
\hline 5 up to 15 years & $0.250 * * *$ & -0.035 & 7.06 & $0.138 * * *$ & -0.051 & 2.74 \\
\hline 15 or more years & $0.309 * * *$ & -0.043 & 7.16 & $0.167 * * *$ & -0.056 & 2.96 \\
\hline \multicolumn{7}{|l|}{ Household Characteristics } \\
\hline Partner present & $0.058 * * *$ & -0.018 & 3.26 & $0.040 *$ & -0.021 & 1.87 \\
\hline \# children aged $0-5$ & $0.021 *$ & -0.011 & 1.93 & 0.007 & -0.012 & 0.59 \\
\hline \# children aged 6-11 & 0.016 & -0.010 & 1.60 & -0.006 & -0.011 & 0.61 \\
\hline \# children aged $12-18$ & $0.023 * *$ & -0.010 & 2.35 & -0.004 & -0.009 & 0.42 \\
\hline \multicolumn{7}{|l|}{ Educational level } \\
\hline Primary & $-0.161 * * *$ & -0.031 & 5.23 & $-0.187 * * *$ & -0.046 & 4.11 \\
\hline Lower secondary & $-0.077 * * *$ & -0.015 & 5.11 & $-0.076 * * *$ & -0.018 & 4.19 \\
\hline Upper secondary & ref. & & & ref. & & \\
\hline 1st stage of tertiary & $0.168 * * *$ & -0.022 & 7.56 & $0.106 * * *$ & -0.019 & 5.46 \\
\hline 2nd stage of tertiary & $0.287 * * *$ & -0.033 & 8.70 & $0.290 * * *$ & -0.025 & 11.57 \\
\hline \multicolumn{7}{|l|}{ Field of education } \\
\hline General & ref. & & & ref. & & \\
\hline Agric/Technics & $-0.036 * *$ & -0.014 & 2.55 & $-0.061 * * *$ & -0.017 & 3.57 \\
\hline Econ/Law & -0.007 & -0.024 & 0.31 & -0.005 & -0.022 & 0.23 \\
\hline Medical & -0.064 & -0.045 & 1.40 & -0.054 & -0.034 & 1.56 \\
\hline Education & $-0.064 * *$ & -0.031 & 2.07 & $-0.059 * *$ & -0.028 & 2.14 \\
\hline Additional wage components & $0.059 * * *$ & -0.014 & 4.31 & $0.074 * * *$ & -0.014 & 5.24 \\
\hline \multicolumn{7}{|l|}{ Firm size } \\
\hline$<25$ employees & ref. & & & ref. & & \\
\hline 25-49 employees & -0.001 & -0.020 & 0.06 & -0.013 & -0.023 & 0.55 \\
\hline 50-499 employees & $0.037 * *$ & -0.016 & 2.32 & 0.003 & -0.017 & 0.18 \\
\hline $500+$ employees & $0.040 * *$ & -0.019 & 2.11 & $0.034 *$ & -0.020 & 1.71 \\
\hline \multicolumn{7}{|l|}{ Supervisory position in job } \\
\hline No supervisory job & ref. & & & ref. & & \\
\hline Supervising 1-4 persons & $0.037 * *$ & -0.017 & 2.22 & $0.036 * *$ & -0.017 & 2.08 \\
\hline Supervising 5-9 persons & $0.082 * * *$ & -0.023 & 3.59 & $0.085 * * *$ & -0.022 & 3.88 \\
\hline
\end{tabular}




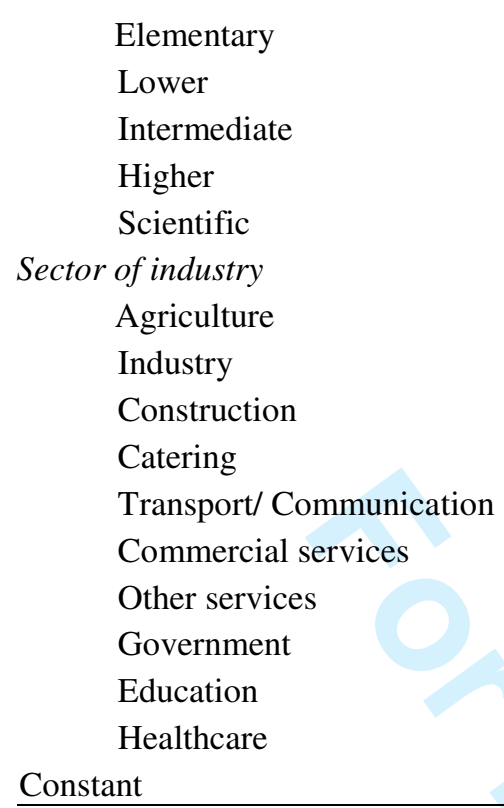
regressions are based on the male sample in both years.

Wages for 1996 are measured in Euro's, and not corrected for price changes.

In contrast, the pay-differences related to differences in educational level increased. In 1996 there is a wage-disadvantage of $16.1 \%$ of not having finished any secondary education. This disadvantage increased to $18.7 \%$ in 2006 . Also, the wage difference between the $1^{\text {st }}$ level of tertiary education and the upper secondary level has become larger. In other words, the distribution widened, and the difference between the first and second stage of tertiary education increased. As women tend to be on average in the slightly lower levels, these changes in the prices might have increased the gender wage gap. A second aspect of education is the field of study. We divided the whole range of educational fields into five groups. Our results show that there is a difference in payment according to these fields (even while we correct for level of education and sector of economy). It turns out that workers who took their education in the technical or agricultural types of education or in the field of 
education earn a relatively low wage. Over the last decade the wage disadvantage for the technical types increased, while the disadvantage for those who completed an education in the field of education diminished (both compared to those workers having only general training). As men are overrepresented in the first group, while women are overrepresented in the second, we expect that this price change has lowered the gender wage gap.

Characteristics of the job are important as well, stressing the statement by Rubery et al. (2002) that wages are determined by more than just human capital. Having additional wage components, like a share of the profits or performance-based pay, for example, results in higher wages, all else constant. Our results also show that there used to be a structural pay difference between firms of different sizes, the larger firms paying slightly higher wages. In 2006, however, this difference has become smaller. Having supervisory tasks is rewarded by a higher wage, the reward being higher the larger the group that has to be supervised. This is the case for both 1996 as 2006, yet the value of having such tasks did decline over the last decade, perhaps related to the fact that having such tasks has become more and more common and no longer needs additional rewards. Next to this job-characteristic, we included a general indicator of the job level. Again, it shows that having a high-level job does result in a higher wage rate. The differences are quite considerable, and apply to all job levels above the basic levels. The changes seem to resemble the changes in the reward of educational level: the wage distribution widened. As women are less likely to work in high level jobs, this development may have contributed to the slow decline in the gender wage gap. Sectoral differences in pay seem to matter only since recently. In 1996, there were no differences in pay levels between sectors.

All these developments in returns and premiums are proof of a changing wage structure. The question remains to what extent these changes are responsible for the persistence of the gender pay gap. In order to answer this question, the next section provides a decomposition of the gender gap for the period 1996-2006.

\section{Decomposition of the Change in the Gender Wage Gap}

The results of Section 4 can be used to decompose the change in the observed raw wage gap into the four components discussed in the previous section: the observed 
characteristics part, the observed prices part, the gap effect and the unobserved prices part. In the observed characteristics and observed prices part, we can show the gap for the various (groups of) explanatory variables. We break these down in three groups: education, life time patterns (age and experience) and finally job and sectorcharacteristics. Table 5 shows the role of these various components in the gender pay gap.

Table 5. Decomposition of the change in the gender wage gap between 1996 and 2006

Decomposition of the gender wage gaps:

raw differential quantity effect residual gap

1996 0.247

0.112

0.135

2006

0.178 0.097

0.081

Changes in the components of the gender gaps

total change quantity effect residual gap

$\begin{array}{lll}-0.069 & -0.016 & -0.053\end{array}$

Decomposition of the change in the quantity effect:

$\begin{array}{ccc}\text { total predicted } & \text { observed X's } & \text { observed } \\ \text { gap } & \text { effect } & \text { prices effect } \\ -0.016 & -0.005 & -0.010 \\ -0.009 & 0.003 & -0.012 \\ -0.012 & -0.005 & -0.007 \\ 0.005 & -0.004 & 0.009\end{array}$

Decomposition of the change in the residual gap

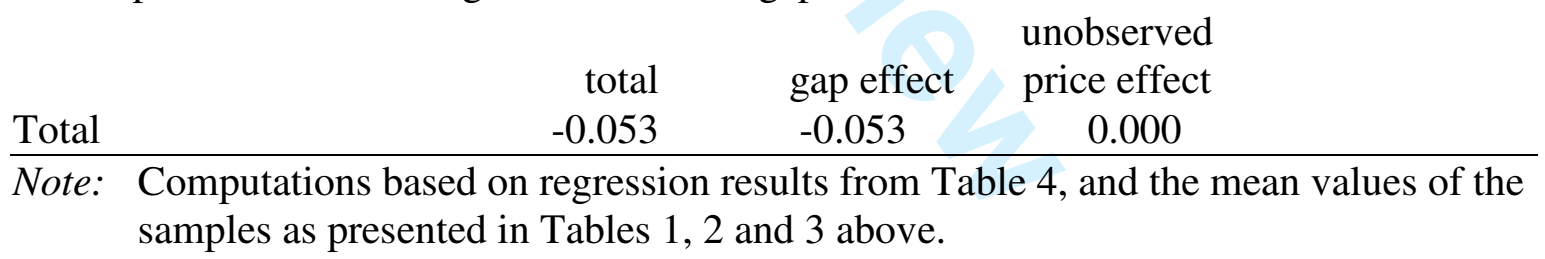

The numbers in Table 5 are computed using the equations in Section IV. From the first panel in the table we can see the raw gender wage gap in both 1996 and 2006. It appears that the quantity effect (i.e. the effect of the difference in observed characteristics between men and women) is around half of the total gender difference in pay, slightly less in 1996, slightly more in 2006, implying that over time the explained part of the gender pay difference became slightly more important compared to the residual gap (the unexplained wage difference between men and women). The different impact of the quantity effect and the residual gap can also be 
seen from the second panel in the table: the total change in the gender wage gap was minus $6.9 \%$. One quarter of this decline (1.6\%) was due to a decline in the quantity effect, three quarters of the decline $(5.3 \%)$ can be attributed to the decrease in the residual gap.

When further breaking down the change in the explained part (the quantity effect) into a change in the difference in observed characteristics and observed prices, using Equations 5 and 6, we get the results in the third panel of Table 5. From these results it can be seen that the changes in the education of male and female workers increased the wage difference, while the change in prices decreased the difference over time. The observed prices effect is the largest, though. Taken together, over half of the total explained change $(0.9 \%)$ can be attributed to education. Changes in age, experience and household composition decreased the wage difference: both the fact that women in the workforce became on average older and more experienced, as well as the fact that long experience is relatively less rewarded in 2006 made that the male-female wage gap declined. The effect of the job-characteristics is mixed: as was noted above, male and female characteristics did slightly converge, leading to a decrease in the gender pay gap. However, the wage structure did also change, more than counteracting this convergence. On this dimension, therefore, the data seem to indicate some 'swimming upstream'.

Finally in the fourth panel the residual gap is broken down into the gap effect as given in Equation 7 and the unobserved price effect as given in Equation 8. The gap effect shows how women changed their position in the residual distribution of the men; the unobserved price effect shows the reward of being in the tails of this residual distribution. Our results show that the unobserved price-effect is completely absent. This is not totally unexpected given the results in our wage regressions: the standard error of the regression remained almost equal, as can be seen from Table 4. In other words, the price of deviating from the mean did not change over time. Therefore, it has to be concluded that two-thirds of the total decline in the wage gap between men and women can be attributed to the fact that women have become more equal to men with respect to unobserved characteristics and/or are treated more similar.

Following Blau and Kahn in adding the gender specific components and the wage structure (i.e. the prices) to each other, the gender specific components (observed X's and the gap effect) add up to -0.059 while the price effects (i.e. the 
wage structure) adds up to -0.010 . Both changes contribute to a decline in the gender wage gap over the last decade, but the effects of changes in the wage structure explain only $15 \%$ of the total change, while changes in the gender specific characteristics explain the other $85 \%$ of the total decline in the wage gap. On the whole, our findings are in contrast with earlier research that showed that women are swimming upstream (Blau and Kahn, 1997; Datta Gupta et al., 2006). The typical pattern of women closing the gap in characteristics, but facing a changing pricestructure that favours 'typical male' characteristics has not occurred in the Netherlands. Rather women seem to be floating downstream as both the characteristics and the prices have contributed in lowering the gender wage gap.

Nevertheless, despite this floating downstream, still a considerable gender wage gap remains. Table 5 indicates that this wage gap is $17.8 \%$, of which over half (9.7 percentage points) can be explained by the quantity effect, i.e. a difference in characteristics between men and women. As a next step, Table 6 provides a decomposition of this quantity effect, indicating that this relates mainly to the job characteristics. More specifically, within the relevant job characteristics the unequal distribution of men and women over the different sectors causes one third of the explained part of the gender pay gap: Male dominated sectors are paid at a higher level than female dominated sectors. This suggests that there is still considerable implicit gender discrimination in the wage structure. In addition, women are still underrepresented in higher level jobs with supervising tasks. This underrepresentation does count for almost $45 \%$ of the explained wage gap.

Table 6. Decomposition of the gender wage gap in 2006

\begin{tabular}{|c|c|c|c|}
\hline & & \multicolumn{2}{|c|}{$\begin{array}{c}\text { components of quantity } \\
\text { effect }\end{array}$} \\
\hline & & & $\begin{array}{c}\% \text { of } \\
\text { quantity } \\
\text { effect }\end{array}$ \\
\hline Total gap & 0.178 & & \\
\hline Quantity effect, total & 0.097 & & \\
\hline education & & -0.002 & $-1.8 \%$ \\
\hline life time patterns & & 0.026 & $27.0 \%$ \\
\hline job characteristics & & 0.072 & $74.7 \%$ \\
\hline of which sector of occupation & & 0.030 & $31.3 \%$ \\
\hline job level indicators & & 0.042 & $43.9 \%$ \\
\hline
\end{tabular}


Residual gap

0.081

Note: Computations based on regression results from Table 4, and the mean values of the samples as presented in Tables 1, 2 and 3 above.

\section{Concluding Remarks}

Despite major improvements in women's labour market attachments, the Dutch gender pay gap is still substantial. According to various sources, women earn approximately $20 \%$ less then men and this difference seems to decrease only slowly. In this article we use Dutch micro-data for 1996 and 2006 from the OSA labour supply panel to study the changes in the gender wage gap. We use the decomposition method of Juhn, Murphy and Pierce.

Our results indicate that 'swimming upstream' does not explain the slow convergence of the male and female wage levels. Although women increased their educational level, men did the same as a result of which the overall gender difference hardly changed. Changes in the observable prices of education did result in a widening of the wage distribution, yet these changes seem to have favoured the closing of the gender wage gap. Women also seem to have caught up in terms of age and experience. In addition, the change in prices made that very long experiences were rewarded less in 2006 compared to 1996. So, both changes in the characteristics and prices contributed to a decline in the gender wage gap. As a result, contrary to what is often found in international literature, between 1996 and 2006 in the Netherlands women did not swim upstream. They increased their labour market attachment and their skills, while at the same time, the wage structure changed in their favour by a decline in the rewards for typical male characteristics.

Still, there is a gender gap of $18 \%$ remaining in 2006. Part of these differences may be related to factors not in our analysis. It is possible, that women tend to have other preferences with respect to the work and wages than men have, resulting in women having on average lower wages, as they aim for other aspects of their work than just payment. In than case we observe 'discrimination' while in fact we tend to observe differences in preferences between men and women. (See e.g. 
Hakim, 2000; 2002). However, of the gap remaining in 2006, over half of the difference is related to differences in observed characteristics. A closer look at our estimation results show that there is still a considerable gender bias in the sectoral pay differences: roughly one third of the explained gender gap in 2006 is explained by the fact that male dominated sectors are paid at a higher level than female dominated sectors. Also, women are still underrepresented in higher level jobs with supervising tasks. With respect to the other half of the gap remaining, our results show that the change in the residual gap can be explained by changes in the unobserved characteristics of men and women, like norms and values, but also to aspects of discrimination. Closing the gender pay gap therefore, still calls for effective policies targeted at stable female labour market participation and banning direct and indirect gender wage discrimination. 


\section{References}

Albrecht, J. W., Van Vuuren, A. and Vroman, S. B. (2004) Decomposing the gender wage gap in the Netherlands with sample selection adjustments, IZA Discussion Paper No. 1400, Forschungsinstitut zur Zukunft der Arbeit (IZA), Bonn.

Blau, F. D. and Kahn, L. M. (1996a) International differences in male wage inequality: institutions versus market forces, Journal of Political Economy, 104, pp. 791-837.

Blau, F. D. and Kahn, L. M. (1996b) Wage structure and gender earnings differentials: an international comparison, Economica, 63, pp. S29-62.

Blau, F. D. and Kahn, L. M. (1997) Swimming upstream: trends in the gender wage differential in the 1980s, Journal of Labor Economics, 15, pp. 1-42.

Blau, F. D. and Kahn, L. M. (2003) Understanding international differences in the gender pay gap, Journal of Labor Economics, 21, pp. 106-44.

Blau, F. D. and Kahn, L. M. (2004) The US gender pay gap in the 1990's: slowing convergence, NBER Working Paper Series no. 10853, National Bureau of Economic Research (NBER), Cambridge, USA.

Blau, F. D. and Kahn, L. M. (2006) The US gender pay gap in the 1990s: slowing convergence, Industrial and Labor Relations Review, 60, pp. 45-66.

Blinder, A. S. (1973) Wage discrimination: Reduced form and structural estimates, Journal of Human Resources, 8, pp. 436-55. 
Borjas, G. J. (1980) The Relationship between Wages and Weekly Hours of Work: The Role of Division Bias, Journal of Human Resources, 15, pp. 409-23.

Datta Gupta, N., Oaxaca, R. L. and Smith, N. (2006) Swimming upstream, floating downstream: comparing women's relative wage progress in the united states and denmark, Industrial and Labor Relations Review, 59, pp. 243-66.

De Ruijter, J. M. P., van Doorne-Huiskes, A. and Schippers, J. J. (2003) Size and causes of the occupational gender wage-gap in the Netherlands, European Sociological Review, 19, pp. 345-60.

Grift, Y. K. (1998) Female labour supply, the influence of taxes and social premiums, Thesis Utrecht University, Utrecht.

Hakim, C. (2000) Work-lifestyle choices in the 21st century: Preference theory. Oxford, NewYork: Oxford University Press.

Hakim, C. (2002) Lifestyle preferences as determinants of women's differentiated labor market careers, Work and Occupations, 29, pp. 428-59.

Heckman, J. J. (1974) Shadow prices, market wages, and labor supply, Econometrica, 42, pp. 679-94.

Heckman, J. J. (1979) Sample selection bias as a specification error, Econometrica, 47, pp. 153-61.

Heinze, A. (2009) Earnings of men and women in firms with a female dominated workforce - what drives the impact of sex segregation on wages? ZEW 
Discussion Paper No. 09-012, Zentrum für Europäische Wirtschaftsforschung (ZEW), Mannheim.

Juhn, C., Murphy, K. M. and Pierce, B. (1991) Accounting for the slowdown in black-white wage convergence, in Workers and their wages, (Ed) M. H. Kosters, American Enterprise Institute Press, Washington DC, pp. 107-43.

Juhn, C., Murphy, K. M. and Pierce, B. (1993) Wage inequality and the rise in returns to skill, Journal of Political Economy, 101, pp. 410-42.

Mandel, H. and Semyonov, M. (2005) Family policies, wage structures, and gender gaps: sources of earnings inequality in 20 countries, American Sociological Review, 70, pp. 949-67.

Oaxaca, R. (1973) Male-female wage differentials in urban labor markets, International Economic Review, 14, pp. 693-709.

OECD. (2002) Employment outlook 2002, Organisation for Economic Cooperation and Development, Paris.

Olsen, W. and Walby, S. (2004) Modelling gender pay gaps, EOC Working papers series No. 17, Equal Opportunities Commission, Manchester.

Plantenga, J. and Remery, C. (2006) The gender pay gap. Origins and policy responses. A comparative review of thirty European countries, European Commission, Luxembourg.

Rubery, J., Grimshaw, D. and Figuereido, H. (2002) The gender pay gap and gender mainstreaming pay policy in EU member states, European Work and 
Employment Research Centre (EWERC), Manchester School of Management, University of Manchester Institute of Science and Technology, Manchester, UK.

Russo, G. and Hassink, W. (2008) The part-time wage gap: a career perspective, De Economist, 156, pp. 145-74.

Schippers, J. J. (1987) Beloningsverschillen tussen mannen en vrouwen - een economische analyse, Thesis Utrecht University, Wolters-Noordhoff, Groningen.

Tijdens, K., Dragstra, A., Dragstra, D., van Klaveren, M., Osse, P., Wetzels, C. and Zorlu, A. (2002) Loonwijzers 2001/2002, werk, lonen en beroepen van mannen en vrouwen in Nederland, AIAS Research Report RR02/10, Amsterdam Institute for Advanced Labour Studies (AIAS), University of Amsterdam, Amsterdam.

Van der Meer, P. H. (2008) Is the gender wage gap declining in the Netherlands? Applied Economics, 40, pp. 149-60.

Vlasblom, J. D. (1998) Differences in labour supply and income of women in the Netherlands and the Federal Republic of Germany, a comparative analysis of the effect of taxes and social premiums, Thesis Utrecht University, Utrecht.

Yun, M. S. (2009) Wage differentials, discrimination and inequality: A cautionary note on the Juhn, Murphy and Pierce decomposition method, Scottish Journal of Political Economy, 56, pp. 114-22. 